How to cite: Taşar, B., Üneş, F., Gemici, E., Varçin, H. (2021) Numerical Simulation of Channel Flow Using Submerged Vane in River Arrangements. 2021 "Air and Water-Components of the Environment" Conference Proceedings, Cluj-Napoca, Romania, p. 119-130, DOI: 10.24193/AWC2021_11.

\title{
NUMERICAL SIMULATION OF CHANNEL FLOW USING SUBMERGED VANE IN RIVER ARRANGEMENTS
}

\author{
Bestami TAŞAR ${ }^{1}$, Fatih ÜNEŞ ${ }^{1 *}$, Ercan GEMICI ${ }^{2}$, Hakan VARÇİ ${ }^{3}$ \\ DOI: 10.24193/AWC2021_11
}

\begin{abstract}
River regulating structures are used in some parts to prevent slope and bed erosion. The main project criterion used for all structures is flow rate or indirect speed. Submerged vane structures are a new alternative method to conventional methods in river regulating structures. In this presented study, the river arrangement study made with submerged vane structures is modeled in 3D. Simulations of the measured flow velocities in the channel, where submerged vane experiments were performed before, were compared with the results of the submerged vane experiment by using the 3-dimensional computational fluid dynamics (CFD) method. In the present CFD model, nonlinear and continuity, turbulence model equations are applied. For the turbulence viscosity, $k-\varepsilon$ turbulence model is used. The results of the present model are compared with the previous experimental work.
\end{abstract}

Keywords: Submerged Vane, Simulation, Velocity, CFD.

\section{INTRODUCTION}

Rivers carry sediment depending on flow conditions. If the sediment carried by the river is below its capacity, bed scour occurs, and if it is above the capacity, sedimentation occurs on the bed. A river regulation structure is built in order to prevent changes in the slope and bottom of the river, to prevent floods, to provide the necessary river depth, to improve the stream and to regulate the groundwater level. Submerged vane structures are a new alternative method to conventional methods in river regulating structures (Fig. 1). Submerged vane structures prevent deterioration of the channel bed by creating reverse circulation (Fig. 2).

The first studies on submerged vanes began in 1982 when Odgaard and Kennedy (1982) introduced the performance of the submerged vane for slope protection on the Sacremento River as a new method as a technical note. Marelius and Sinha (1999) stated that a definite relationship cannot be given between the submerged vane placement angle and sediment inflow into the lateral channel. It has been stated that even the bed roughness is effective in orientation even if all conditions are the same.

1 Iskenderun Technical University, Iskenderun/Hatay - TURKEY, e-mail: bestami.tasar@iste.edu.tr , fatih.unes@iste.edu.tr*corresponding author, hakan.varcin@iste.edu.tr

2 Bartin University, Bartin - TURKEY, e-mail: egemici@bartin.edu.tr 
Barkdoll (1999) examined the effect of submerged vane angle on the water intake. Ghorbani and Kells (2008) investigated the effect of the submerged vane on carving around a cylindrical foot. Ouyang et al. (2008) investigated the interaction

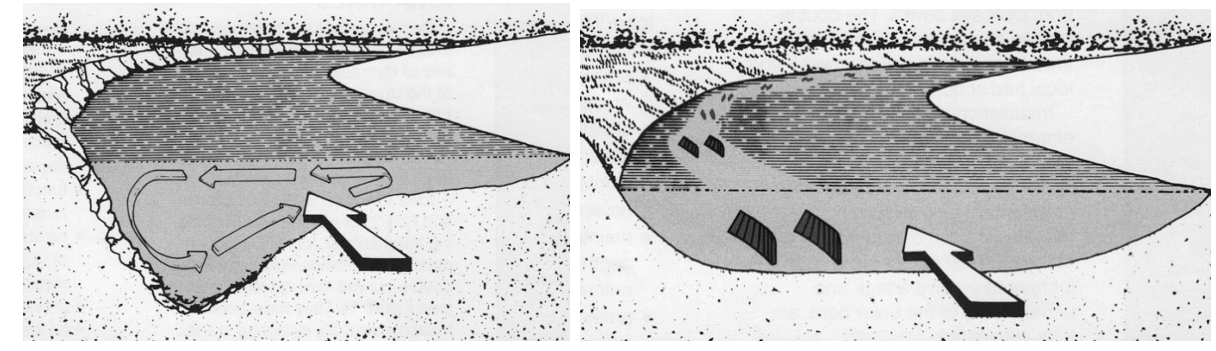

Fig. 1. Submerged vane effect on river (Odgaard,2009)

of rows of vanes in a curved channel. He stated that in a system in which three vanes are lined up, as the vane span decreases, its effect on sediment management decreases. Gupta et al. (2010) tried to eliminate the carving around the vane with the help of a circular ring attached to the front end of the submerged vanes. Ouyang and Lai (2013) optimized the submerged vane design using a genetic algorithm. The vanes used to consist of a flat semi-ellipsoid profile with beveled edges.

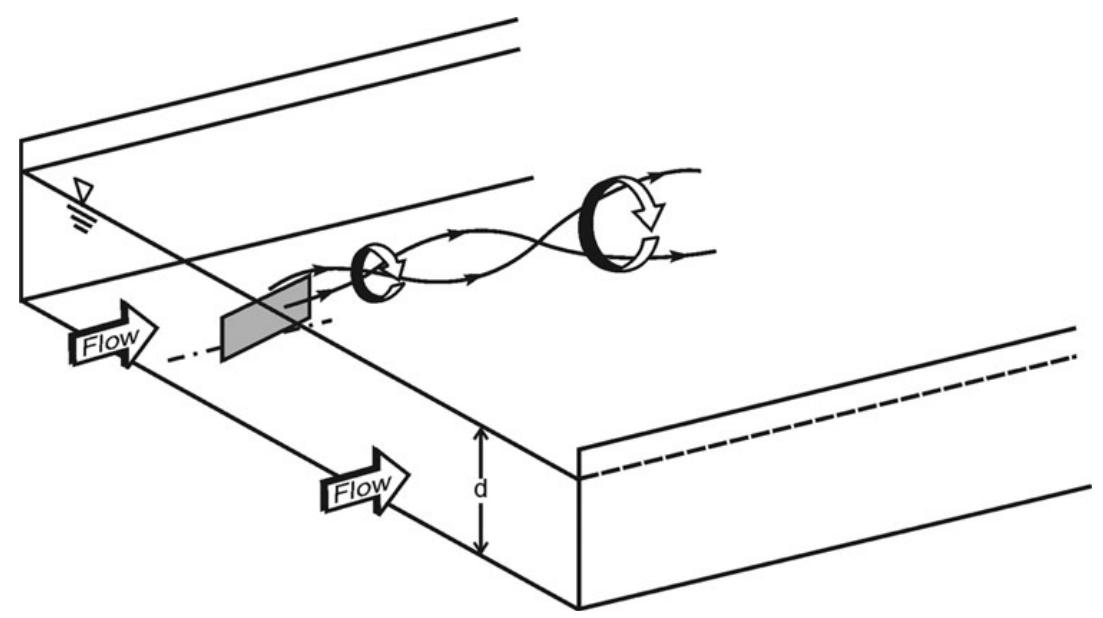

Fig. 2. Streamflow circulation after submerged vane (Odgaard,2009)

It is important to verify numerically in the analysis and design of hydraulic structures that interact with the water flow. In addition to the information and findings obtained from experimental studies, numerical calculation methods are based on theoretical modeling. Due to the fact that modeling is faster and more economical, the analysis of water-structure interaction problems with numerical methods attracts more attention today. The free surface and velocity profiles of the 
flow can be determined in detail by numerically solving the basic equations governing the flow with Computational Fluid Dynamics (CFD) methods.

The volume of fluid (VOF) method has been used successfully for the analysis of turbulent flows interacting with water structures (Gümüş et al. (2013),). There is a need for more studies to verify numerical solutions based on the VOF method with experiments in CFD applications (Ispir et al. (2014)).

Üneş (2008a) and Üneş (2008b) studied 3D mathematical model which including Coriolis force to investigate the characteristic parameters of the density flow. Üneş et al. (2013) used a numerical model that was derived to investigate the characteristic parameters of the density and plunging flow in a dam reservoir in their study.

For turbulent viscosity, they used a k- $\varepsilon$ turbulence model. Üneş et al. (2014) applied the 2-dimensional model to simulate density and subduction flow in a reservoir with an inclined bottom. Üneş and Varçin (2015) developed a 3D hydrodynamic model of a real dam reservoir to simulate a real dam reservoir flow for different seasons. Üneş and Ağiralioğlu (2017) studied density plunging (buoyant) flow in the dam reservoir and velocity, temperature and turbulence viscosity variation through the dam reservoir determined by simulation results.

Kocaer and Yarar (2020) studied the flow over ogee type spillway by performing experiments in an open channel flume in the laboratory and simulating with a numerical model.

Gemici (2015) examined the effects of different channel width / channel depth, submergence / vane height ratios, Froude numbers, vane arrangement, vane length / vane height, and approach angle combinations on flow velocity upstream and downstream when the side channel is open or closed. Mohammadiun et al. (2016) investigated the performance of vanes in terms of reducing maximum velocity after the junction with various discharge ratios. Kocabaş et al. (2016) investigated the effects of submergence / vane height, vane length / vane height, and approach angle of flow velocity at the upstream and downstream.

The main purpose of this study is to verify and compare the velocity measurements of the triple-lined submerged vane model by experimental and numerical methods, which were previously experimented (Gemici, 2015) in the open channel flume.

\section{DATA AND METHODS}

\subsection{Data used}

In this paper, the 3-dimensional (3D) analysis was built up for previously 20degree submerged vane structures. The design and 3D computational fluid dynamics (CFD) model was created according to the open channel experiment setup consisting of 1 main and 1 side channel (Fig. 3.). According to the reference study, initial conditions, boundary layer conditions are established and will be compared with the test results. 


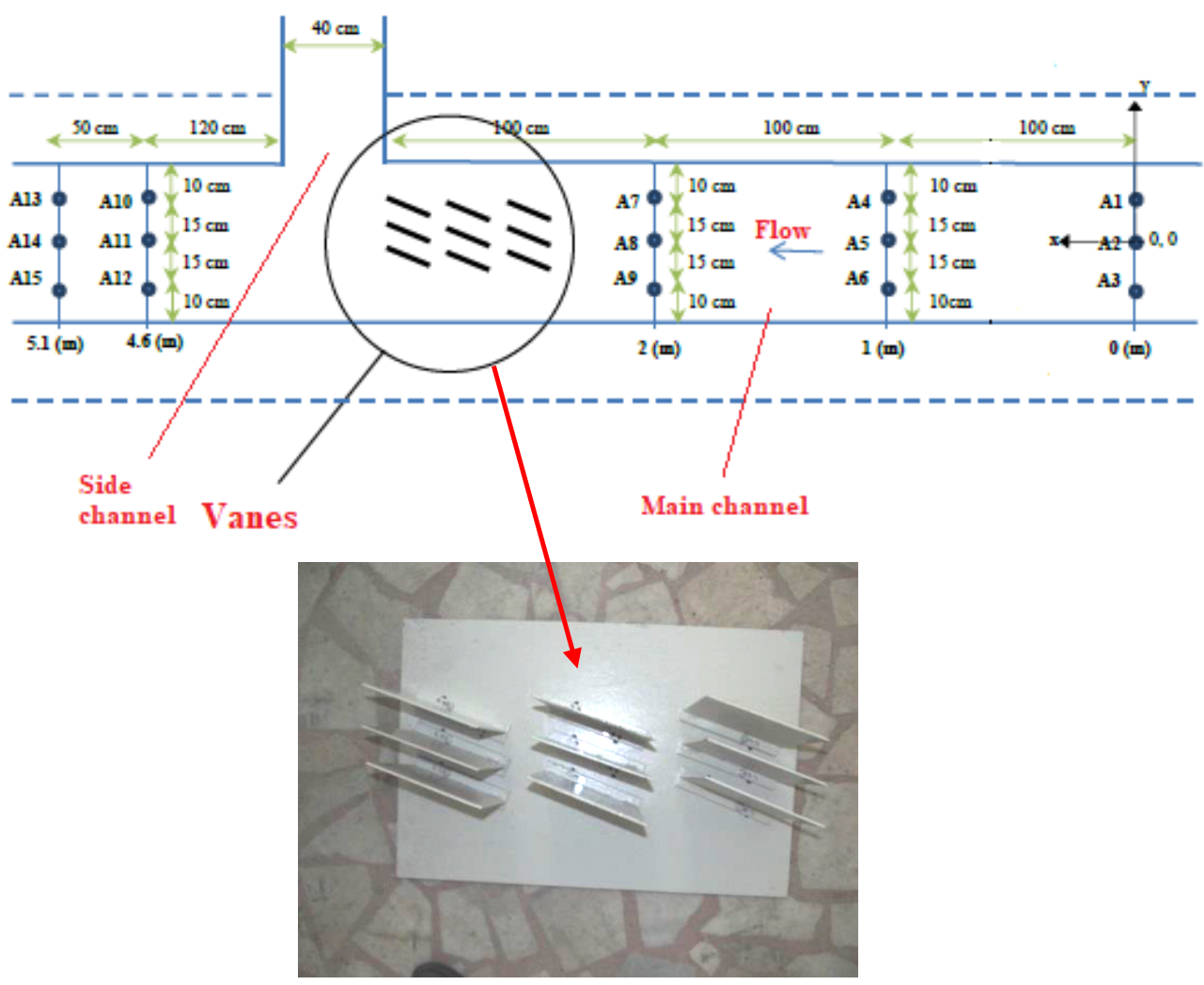

Fig. 3. Submerged vane experiment set-up (top); Submerged vane lined up with 20 degrees (bottom) (Gemici, 2015)

\subsection{Methods}

\subsubsection{Basic Equations}

In computational fluid dynamics, the volume of fluid (VOF) method is a free surface modeling technique, that is, a numerical method for tracking and positioning the free surface. It belongs to the Eulerian class of methods. Navier-Stokes equations describing the motion of the flow must be solved separately. The VOF model can model two or more immiscible liquids by solving the set of momentum equations and tracking the volume fraction of each of the fluids.

The investigated open channel flow is a 3D, non-compressive, turbulent, steady free surface flow. The basic equations governing flow, conservation of mass, and conservation of momentum (Navier-Stokes with Reynolds averages, RANS) equations are as follows:

$$
\frac{\partial \rho}{\partial t}+\frac{\partial(\rho \bar{u})}{\partial x}+\frac{\partial(\rho \bar{v})}{\partial y}+\frac{\partial(\rho \bar{w})}{\partial z}=0
$$


In Eq. 1 , Here, $\overline{\mathrm{u}} ; \bar{v} ; \bar{w}$ and $\mathrm{u}^{\prime} ; v^{\prime} ; w^{\prime}$ respectively give the temporal average velocity of the velocity components and swash turbulence in the $\mathrm{x}, \mathrm{y}$, and $\mathrm{z}$ directions. RANS equations along the $\mathrm{x}-\mathrm{y}-\mathrm{z}-\mathrm{ax}$ is are as follows.

$$
\begin{aligned}
& \rho\left(\frac{\partial \bar{u}}{\partial t}+\bar{u} \frac{\partial \bar{u}}{\partial x}+\bar{v} \frac{\partial \bar{u}}{\partial y}+\bar{w} \frac{\partial \bar{u}}{\partial z}\right)=\rho K_{x}-\frac{\partial \bar{P}}{\partial x}+\mu \nabla^{2} \bar{u}+\frac{\partial}{\partial x}\left(-\rho \overline{u^{\prime 2}}\right)+\frac{\partial}{\partial y}\left(-\rho \overline{u^{\prime} v^{\prime}}\right)+\frac{\partial}{\partial z}\left(-\rho \overline{u^{\prime} w^{\prime}}\right) \\
& \rho\left(\frac{\partial \bar{v}}{\partial t}+\bar{u} \frac{\partial \bar{v}}{\partial x}+\bar{v} \frac{\partial \bar{v}}{\partial y}+\bar{w} \frac{\partial \bar{v}}{\partial z}\right)=\rho K_{y}-\frac{\partial \bar{P}}{\partial y}+\mu \nabla^{2} \bar{v}+\frac{\partial}{\partial x}\left(-\rho \overline{u^{\prime} v^{\prime}}\right)+\frac{\partial}{\partial y}\left(-\rho \overline{v^{\prime 2}}\right)+\frac{\partial}{\partial z}\left(-\rho \overline{v^{\prime} w^{\prime}}\right) \\
& \rho\left(\frac{\partial \bar{w}}{\partial t}+\bar{u} \frac{\partial \bar{w}}{\partial x}+\bar{v} \frac{\partial \bar{w}}{\partial y}+\bar{w} \frac{\partial \bar{w}}{\partial z}\right)=\rho K_{z}-\frac{\partial \bar{P}}{\partial z}+\mu \nabla^{2} \bar{w}+\frac{\partial}{\partial x}\left(-\rho \overline{u^{\prime} w^{\prime}}\right)+\frac{\partial}{\partial y}\left(-\rho \overline{v^{\prime} w^{\prime}}\right)+\frac{\partial}{\partial z}\left(-\rho \overline{w^{\prime 2}}\right)
\end{aligned}
$$

These equations are written in a vectorial form as:

$\rho\left(\frac{\partial \vec{V}}{\partial t}+\vec{V} . \nabla \vec{V}\right)=\overrightarrow{\rho K}-\nabla \bar{P}+\mu \nabla^{2} \vec{V}+\nabla \cdot \tau_{\mathrm{ij}}{ }^{\prime}$

Here; "K" refers to the mass forces, "P" refers to the compressive force, " $\mu$ " to the dynamic viscosity, " $\tau_{\mathrm{ij}}{ }^{\prime \prime}$ " to Reynolds stresses. Turbulence models undertake the task of calculating " $\tau_{\mathrm{ij}}{ }^{\prime}$ " in Reynolds stresses equation and thus solving the equation system. In this study, the Standard k- $\varepsilon$ (SKE) (Launder \& Spalding, 1972) turbulence model was used. Standard $k-\varepsilon$ model is based on model transport equations for turbulent kinetic energy $(\mathrm{k})$ and its dissipation rate $(\varepsilon)$. For a three dimensional unsteady flow at the open channel, the eddy viscosity $v_{\mathrm{t}}$ is computed from the following equation,

$v_{t}=C_{\mu} \frac{k^{2}}{\varepsilon}$

where $k$ is the turbulent kinetic energy and $\varepsilon$ is the turbulent energy dissipation rate per unit mass. $k$ and $\varepsilon$ are obtained from the solution of the following equations in three-dimensional flow.

Equation of $\mathrm{k}$

$\frac{\partial k}{\partial t}+\bar{u}_{j} \frac{\partial k}{\partial x_{j}}=\frac{\partial}{\partial x_{j}}\left[\left(v+\frac{v_{t}}{\sigma_{k}}\right) \frac{\partial k}{\partial x_{j}}\right]+\operatorname{Prod}+G-\varepsilon$

and equation of $\varepsilon$,

$\rho \frac{\partial \varepsilon}{\partial t}+\bar{u}_{j} \frac{\partial \varepsilon}{\partial x_{j}}=\frac{\partial}{\partial x_{j}}\left[\left(v+\frac{v_{t}}{\sigma_{\varepsilon}}\right) \frac{\partial \varepsilon}{\partial x_{j}}\right]+C_{1 \varepsilon} \frac{\varepsilon}{k} \operatorname{Pr} o d-C_{2 \varepsilon} \frac{\varepsilon^{2}}{k}+C_{1 \varepsilon} C_{3} \frac{\varepsilon}{k} G$

where Prod is the production of turbulent kinetic energy from the mean flow and is given as

$$
\operatorname{Prod}=v_{t}\left(\frac{\partial \bar{u}_{i}}{\partial x_{j}}+\frac{\partial \bar{u}_{j}}{\partial x_{i}}\right) \frac{\partial \bar{u}_{i}}{\partial x_{j}}
$$


In these equations, $G$ is the production or destruction of turbulent kinetic energy by buoyancy forces and is given as

$$
G=g_{i} \beta \frac{v_{t}}{\sigma_{t}} \frac{\partial \bar{V}}{\partial x_{i}}
$$

where, $\beta$ is thermal expansion coefficient. In addition, the values of the coefficients $C_{\mu}, C_{1 \varepsilon}, C_{2 \varepsilon}, C_{3}, \sigma_{k}, \sigma_{\varepsilon}$ and $\sigma_{t}$ appearing in the k- $\varepsilon$ turbulence model equations used herein were given the standard values recommended by Launder and Spalding (1974).

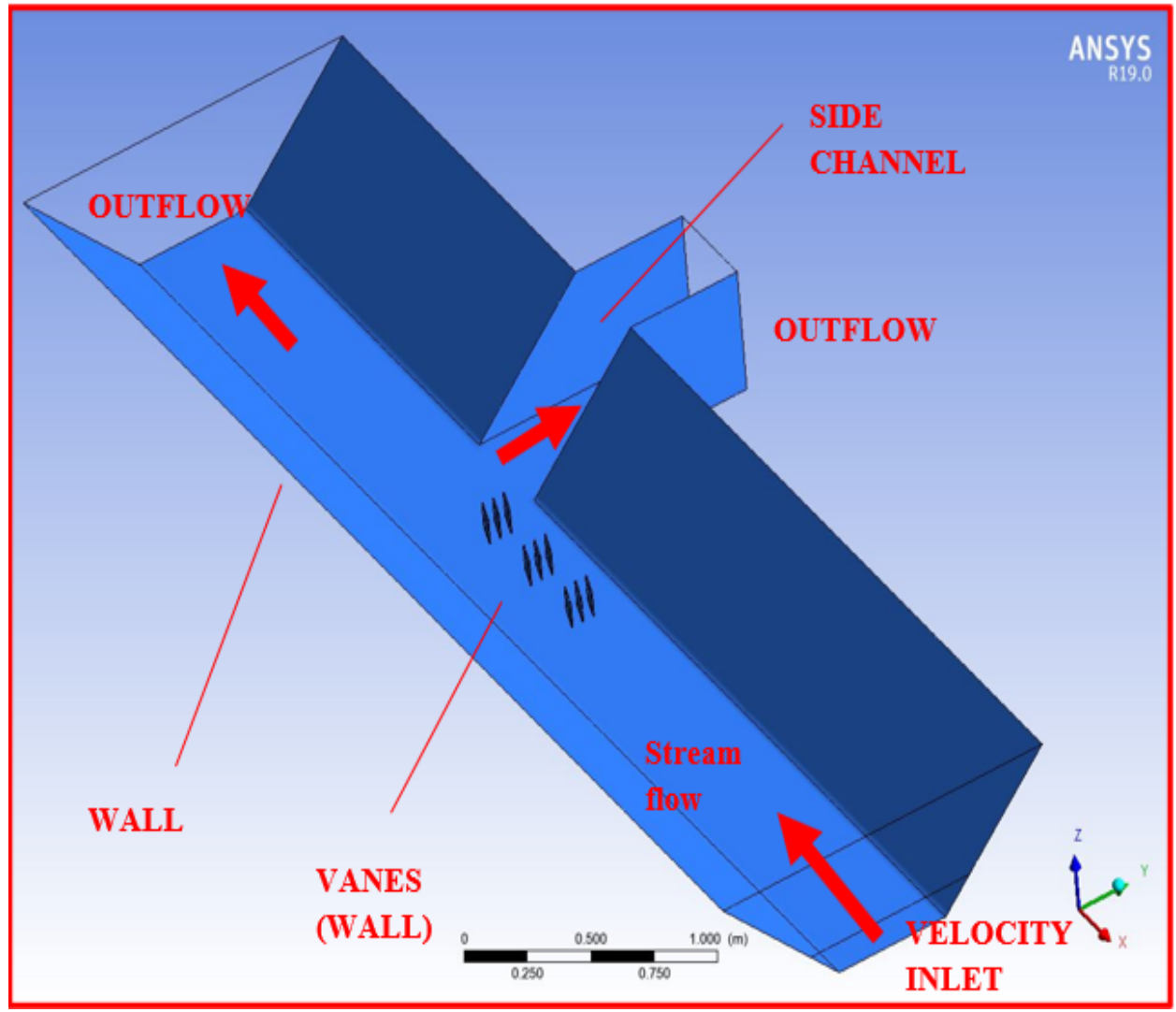

Fig. 4. Submerged vane boundary conditions

Since the current in the open channel is the current that changes with time, these initial values and conditions change during the current simulation and are not extremely important as they adapt to the current over time.

In Table 1, the initial values required for the establishment of the model are given. In the numerical model simulations, the flow rates measured in the open channel were influenced, and other boundary conditions were taken in accordance with the measurement values made in the setup. 
Table 1. Submerged vane initial conditions

\begin{tabular}{|c|c|c|}
\hline \multicolumn{2}{|c|}{ Main Channel } & Side Channel \\
\hline $\begin{array}{c}\text { Velocity Inlet }\left(\mathrm{V}_{\mathrm{i}}\right. \\
(\mathrm{m} / \mathrm{s}))\end{array}$ & $\begin{array}{c}\text { Water inlet depth } \\
\left(\mathrm{d}_{\mathrm{i}}, \mathrm{m}\right)\end{array}$ & $\begin{array}{c}\text { Outflow } \\
\left(\mathrm{Q}_{\mathrm{O}},\left(\mathrm{m}^{3} / \mathrm{s}\right)\right)\end{array}$ \\
\hline 0.389 & 0.123 & 0.006 \\
\hline
\end{tabular}

The model simulations for the flow with submerged vanes given in the figures above were created and solved by using GAMBIT and ANSYS-FLUENT R19.0 package programs, with the equations forming the numerical model under appropriate boundary and initial conditions. Control volume approach was used as a solution method. In this model, a network of accounts was created using nearly 312000 tetrahedral calculation cells.

\section{RESULTS AND DISCUSSIONS}

By considering the boundary conditions, the CFD flow velocity 3D model results at the main and side channel are given in Fig. 5.

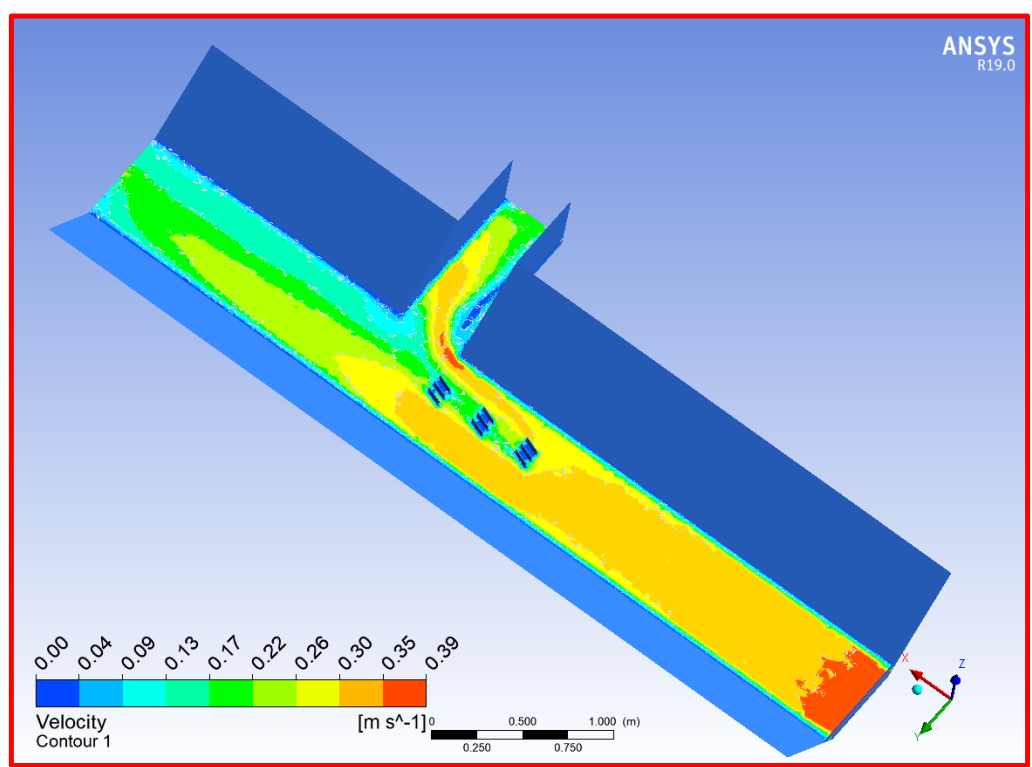

Fig. 5. Velocity contour fluctuation with Submerged vane at main-side channel

According to Figure 5, it has been observed that the speed decreases in the regions where there is submerged vane. It was observed that the velocities of $0.17-0.22 \mathrm{~m} / \mathrm{s}$ belonging to the green contours were observed in the region where the vane is, while these velocities were yellow in the vane edges and front with a higher value $(0.30-$ 
$0.35 \mathrm{~m} / \mathrm{s}$ ). In Figure 6 , the vectorial and streamline representation of the velocity changes in the main and side channels of the submerged vane structures is given.

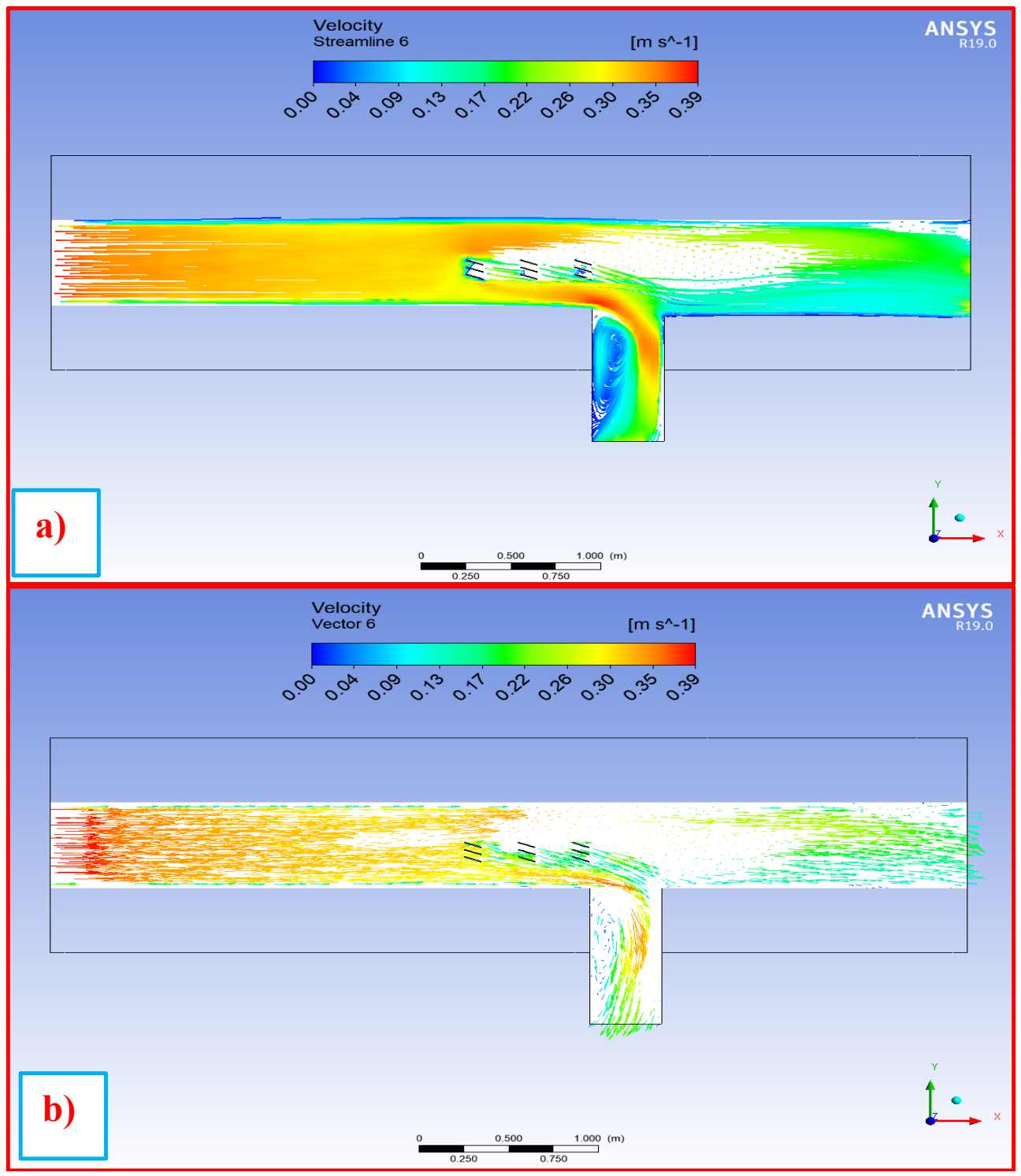

Fig. 6. Velocity fluctuation with Submerged vane at main-side channel: a) Streamline b) vector

According to Figures 6-a and b, submerged vane structures help flow direction. It was observed that there were flow transitions from the main channel to the side channel. It can be seen from the shapes that speed drops are experienced in the regions close to the vane and in the areas after the vane. Table 2 shows the results of 
the Experimental (Gemici, 2015) and Ansys-fluent CFD for the 5 sections shown in the figure 3.

Table 2. CFD and experiment results for velocity fluctuations

\begin{tabular}{|c|c|c|c|c|}
\hline $\begin{array}{c}\text { Section } \\
\text { No }\end{array}$ & $\begin{array}{c}\text { Location at } \mathbf{x} \\
\text { direction (m) }\end{array}$ & $\begin{array}{c}\text { Experiment } \\
\text { Results (m/s) }\end{array}$ & $\begin{array}{c}\text { Ansys Fluent } \\
\text { CFD Results } \\
(\mathbf{m} / \mathbf{s})\end{array}$ & $\begin{array}{c}\text { Error } \\
(\%)\end{array}$ \\
\hline 1 & 0.0 & 0.3894 & 0.3890 & $0.11 \%$ \\
\hline 2 & 1.0 & 0.3768 & 0.3485 & $7.50 \%$ \\
\hline 3 & 2.0 & 0.3716 & 0.3391 & $8.75 \%$ \\
\hline 4 & 4.6 & 0.2276 & 0.2153 & $5.40 \%$ \\
\hline 5 & 5.1 & 0.2199 & 0.2012 & $8.52 \%$ \\
\hline
\end{tabular}

According to Table 2, the lowest error rate was $0.1 \%$ and the highest error rate was $7.5 \%$ at positions 0,1 , and 2 meters before vane. After vane, at 4.6 and 5.1 meters from starting point, $5.40 \%$ and 8.52 error rates were obtained. The display of the current average velocity changes obtained in Table 2 is given in Figure 7.

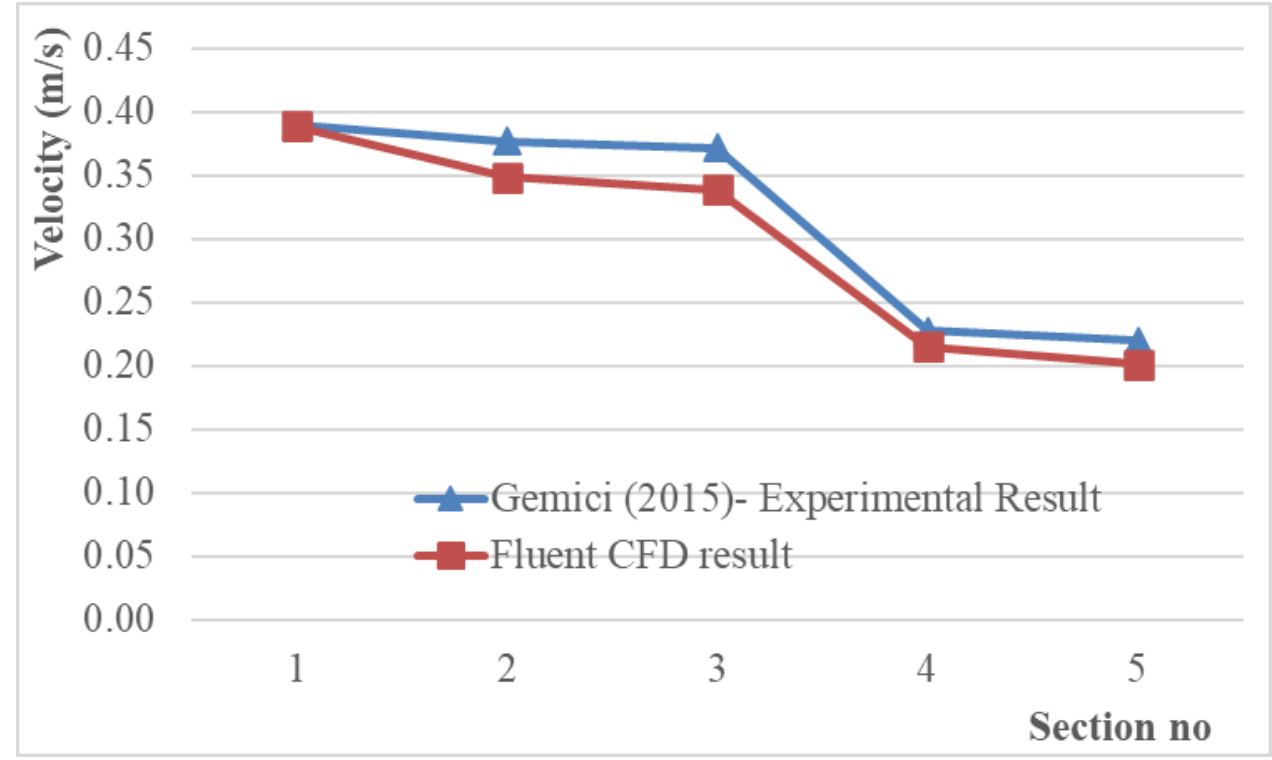

Fig. 7. Examination of change in experimental and model velocity fluctuation results along the channel

Information on the sections mentioned in Table 2 and the change of 5 crosssectional velocity distributions are given in Figure 8. 


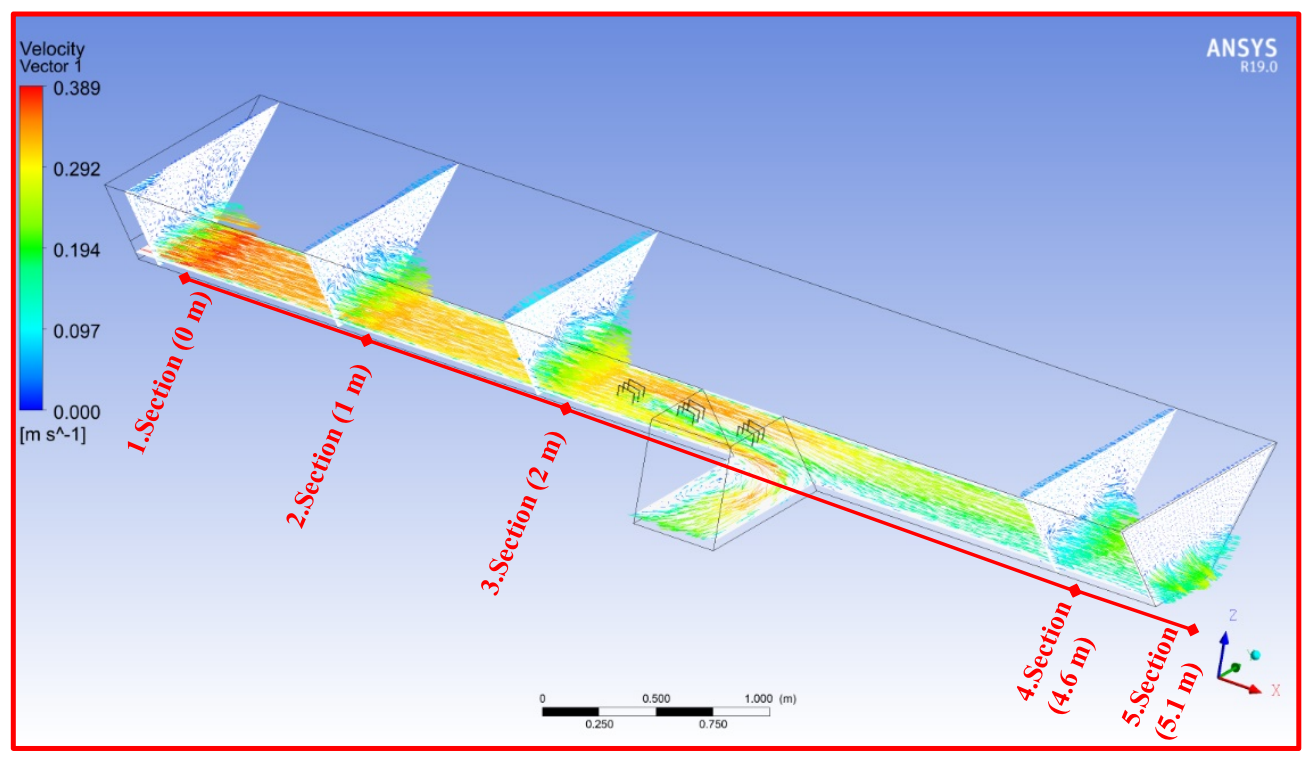

Fig. 8. Variation of 5 cross-sectional velocity distributions using CFD

\section{CONCLUSIONS}

In this study, an open channel flow was modeled in 3D using the submerged vane structure and the results obtained were compared with the results of the measurements obtained in the laboratory. It was determined that the model results were compatible with the results of the previous experiments. Performed models show that the established mathematical model is correct, and the results can be evaluated.

Mathematical model results show that, with this type of operation and an acceptable error, the current and effects that may occur at every point throughout the channel can be determined. The data obtained as a result of the research can be used in the determination of the change in the characteristics of the open channel flow and in the studies related to open channel velocity changes induced by submerged vanes.

The resulting mathematical model simulation can be used to simulate the effects of the submerged vane structure at each point of the river before the river arrangement is made. In addition, flow parameters such as water pressure, flow velocity, turbulence, which are very difficult and expensive to determine with flow in rivers, can be determined using CFD. Good results are obtained before applying the submerged vane structure.

\section{REFERENCES}

1. Odgaard, A. J., \& Kennedy, J. F. (1982). Analysis of Sacramento River bend flows, and development of a new method for bank protection. Iowa Inst Of Hydraulic Research Iowa City. 
2. Marelius, F., Sinha, S. K., 1999. Experimental Investigation of Flow Past Submerged Vanes - Closure. Journal of Hydraulic Engineering, ASCE, 125 (8): 898-899.

3. Barkdoll, B., 1999. Experimental Investigation of Flow Past Submerged Vanes. Journal of Hydraulic Engineering, ASCE, 125 (8): 896-898.

4. Ghorbani, B., Kells, J. A., 2008. Effect of Submerged Vanes on the Scour Occurring at a Cylindrical Pier. Journal of Hydraulic Research, 46 (5): 610-619.

5. Ouyang, H. T., Lai, J. S., Yu, H., 2008. Interaction Between Submerged Vanes for Sediment Management. Journal of Hydraulic Research, 46 (5): 620-627.

6. Odgaard, A. J. (2009, April). River training and sediment management with submerged vanes. American Society of Civil Engineers.

7. Gupta, U. P., Ojha, C. S. P., Sharma, N., 2010. Enhancing Utility of Submerged Vanes with Collar. Journal of Hydraulic Engineering, ASCE, 136 (9): 651-655.

8. Ouyang H.T., Lai, J. S., 2013. Design Optimization of a Submerged Vane with Streamlined Profile for Sediment Management in Rivers. Journal of Marine Science and Technology-Taiwan, 21 (3): 325-332.

9. Gümüş, V., Aköz, M., \& Kirkgöz, M. (2013). Experimental and Numerical Modeling of Submerged Hydraulic Jump Downstream of a Sluice Gate.

10.Ispir, M. A., Kirkgöz, M. S., \& Gümüş, V. Yavaş Değişen Kritik-Altı Açık Kanal Akımının k- $\varepsilon$ Türbülans Kapatma Modelleri ile Sayısal Hesabı. Çukurova Üniversitesi Mühendislik-Mimarlık Fakültesi Dergisi, 29(1), 145-156 (in Turkish).

11. Üneş, F. (2008a). Analysis of plunging phenomenon in dam reservoirs using threedimensional density flow simulations. Canadian Journal of Civil Engineering, 35(10), 1138-1151.

12. Üneş, F. (2008b). Investigation of density flow in dam reservoirs using a threedimensional mathematical model including Coriolis effect. Computers \& fluids, 37(9), 1170-1192.

13. Üneş, F., Ağiralioğlu, N., \& Demirci, M. (2013). Simulation of Density Flow in Dam Reservoirs Using Two Dimensional Mathematical Models. International Balkans Conferance on Challenges of Civil Engineering, BCCCE, 19-21 May 2011, EPOKA University, Tirana, ALBANIA

14. Ünes, F., Agiralioglu, N., \& Demirci, M. (2014). Simulation of Density Flow and Velocity Variation in Dam Reservoirs. Journées de l'hydraulique, 36(1), 1-13.

15. Üneş, F., \& Varçin, H. (2015). Investigation of seasonal thermal flow in a real dam reservoir using 3-D numerical modeling. Journal of Hydrology and Hydromechanics, 63(1), 38-46.

16. Üneş, F., \& Ağiralioğlu, N. (2017). Numerical Investigation of Temporal Variation of Density Flow and Parameters. Journal of Applied Fluid Mechanics, 10(1), 81-94.

17. Kocaer, Ö., \& Yarar, A. (2020). Experimental and Numerical Investigation of Flow Over Ogee Spillway. Water Resources Management, 34(13), 3949-3965.

18. Gemici, E. (2015). Açık Kanallarda Batık Kanatlarla Akım Yönetimi, Erciyes Üniversitesi. Fen Bilimleri Enstitüsü, Doktora Tezi. (in Turkish).

19. Kocabaş, F., Gemici, E., \& Ardiçlioğlu, M. (2016). Dikdörtgen Kesitli Açık Kanallarda Batık Kanatların Şev Stabilitesi Üzerinde Etkisi. Mühendislik ve Teknoloji Bilimleri Dergisi, 4(1), 1-7 (in Turkish).

20. Mohammadiun, S., Neyshabouri, S. S., Naser, G., \& Vahabi, H. (2016). Numerical investigation of submerged vane effects on flow pattern in a 90 junction of straight 
and bend open channels. Iranian Journal of Science and Technology, Transactions of Civil Engineering, 40(4), 349-365.

21. Launder, B.E., ve Spalding, D.B.,1972. Mathematical models of Turbulence, Academic Press, Newyork.

22. Analysis Systems Inc., ANSYS fluent, Fluid Simulation software 